Diabetologia 10, 353-355 (1974)

(c) by Springer-Verlag 1974

\title{
Intestinal Brush Border Enzyme Activity in Juvenile and Maturity Onset Diabetes Mellitus*
}

\author{
W.F. Caspary, K. Winckler, W. Creutzfeldt
}

Division of Gastroenterology and Metabolism, Department of Medicine, University of Göttingen, W.-Germany

Received: February 18, 1974

Summary. Small intestinal enzymatic activities of disaccharidases, alkaline phosphatase and peptide hydrolases have been measured in small bowel biopsy material of healthy controls and patients with maturity and juvenile onset diabetes. In contrast to increased digestive enzymatic activities in experimental diabetes mellitus, juvenile and maturity onset diabetics did have normal dig'estive activities for hydrolysis of disaccharides and oligopeptides.

Key words: Diabetes mellitus and mucosal enzymes, disaccharidases, peptide hydrolases, alkaline phosphatase.
An increase of intestinal brush border hydrolase activity in the mucosa of streptozotocin $[3,4]$ as well as alloxan-diabetic rats $[11,14,18]$ has been shown recently. Cerda, Preiser and Crane [6] found elevated disaccharidase activities in small bowel biopsies from patients with chronic pancreatic insufficiency and diabetes mellitus. In order to find out whether diabetes mellitus without exocrine pancreatic insufficiency is also associated with an increased digestive capacity we examined enzymatic activities of disaccharidases,

\section{Methods}

Patients who consented to the procedure were fasted overnight. Multiple small bowel biopsies were then obtained with a hydraulic biopsy tube (Quinton Instruments, Seattle, Washington, USA), under fluoroscopic control, beyond the ligament of Treitz. Biopsies for light microscopy and enzymatic analysis were taken from three groups of patients: $A=10$ patients without gastrointestinal disease and normal

Table 1. Clinical data on diabetics examined for intestinal mucosal enzymes

\begin{tabular}{|c|c|c|}
\hline & $\begin{array}{l}\text { Maturity onset diabetics } \\
\text { (Group B) }\end{array}$ & $\begin{array}{l}\text { Juvenile diabetics } \\
\text { (Group C) }\end{array}$ \\
\hline Number of patients & 10 & 5 \\
\hline Mean age (years) & $\begin{array}{l}59.1 \pm 9.4 \\
\text { (range: } 45-72 \text { ) }\end{array}$ & $\begin{array}{l}37.4 \pm 17 \\
\text { (range: } 20-54 \text { ) }\end{array}$ \\
\hline Diabetes known since (years) & $\begin{array}{l}2.4 \pm 2.2 \\
\text { (range: } 1 \text { week }-5 \text { years }\end{array}$ & $\begin{array}{l}13.0 \pm 10.7 \\
\text { (range: } 2 \text { weeks }-25 \text { years) }\end{array}$ \\
\hline $\begin{array}{l}\text { Mean postprandial blood glucose }(\mathrm{mg} / 100 \mathrm{ml}) 24 \mathrm{~h} \\
\text { befor biopsy } \\
\text { Treatment: }\end{array}$ & $189 \pm 68.7$ & $184 \pm 58$ \\
\hline Diet only & $5 / 10$ & $1 / 5^{\mathrm{a}}$ \\
\hline Sulfonylureas only & $3 / 10$ & $0 / 5$ \\
\hline Butylbiguanide and Sulfonylurea & $1 / 10$ & $0 / 5$ \\
\hline Insulin & $1 / 10$ & $4 / 5$ \\
\hline
\end{tabular}

a In one 20 year old patient with diabetes mellitus on admission the biopsy was obtained before he had any insulin. $\mathrm{He}$ had polyuria and polydipsia 2 weeks prior to admission. (Blood glucose: $352 \mathrm{mg} / 100 \mathrm{ml}$, glucosuria: $8.5 \mathrm{~g} / 100 \mathrm{ml}$, ketonuria).

Results are means \pm S.D.

alkaline phosphatase and peptide hydrolases in jejunal mucosal biopsies from juvenile and maturity onset diabetics and from a control group with normal glucose tolerance. Since brush border disaccharide hydrolysis and transport of the split products across the mucosal wall are functionally closely associated processes in the brush border membrane of intestinal mucosal cells $[4,12]$, it is of interest whether the activity of digestive enzymes is increased in human diabetes mellitus.

* Part of the results has been presented at the 28 . Tagung der Deutschen Gesellschaft für Verdauungs- und Stoffwechselkrankheiten, Erlangen, September 1973 glucose tolerance; $\mathrm{B}=10$ patients with maturity onset diabetes having no gastrointestinal disease; $\mathrm{C}=5$ patients with juvenile onset diabetes requiring insulin-treatment. The last insulin injection was given $24 \mathrm{~h}$ before taking the biopsy. Further clinical data (age, duration of diabetes, postprandial blood glucose, treatment) are given in Table 1. The mucosal biopsies were immediately screened under the stereo-microscope Part of the tissue was fixed in $4 \%$ formol. Paraffin sections were stained with haematoxylin-eosin and PAS. Part of the tissue was used for biochemical analysis.

Disaccharidase activity (maltase, sucrase, lactase, 
trehalase) was measured according to the method of Dahlqvist [9]; alkaline phosphatase was determined with $\mathrm{p}$-phenylphosphate as the substrate (pH 10.5). Peptide hydrolase activity was measured by the method of Fujita, Parsons and Woinarowska [10] adapted for human small bowel biopsies [5]. Protein was assayed by the method of Lowry et al. [12], using bovine serum albumin as standard. All enzymatic assays were performed in triplicates. Results are expressed in specific activities (umoles of substrate hydrolyzed $/ \mathrm{min} / \mathrm{mg}$ or $\mathrm{g}$ of protein). Statistical analysis was done using Student's t-test.

\section{Results}

All biopsies showed normal villous structure and histology revealed no signs of mucosal atrophy or inflammation. Brush border disaccharidases (maltase, sucrase, lactase, trehalase) and alkaline phosphatase did not significantly differ in jejunal mucosa of diabetics compared with non-diabetic controls (Table 2). Patients with maturity onset diabetes had di- diction to animal experiments demonstrating increased digestive enzymatic activities in experimental diabetes mellitus of rats $[3,4,11,14,18]$. However, the increased sugar and amino acid transport capacity as well as the increased digestive enzymatic activity in experimental diabetes mellitus can be reversed by insulin-treatment $[3,4]$.

The finding of normal activity of intestinal brush border enzymes in human diabetes mellitus could be explained by the good or fair metabolic control at the time of biopsy. However, the presence of normal digestive enzymatic activity in one severely diabetic patient with ketonuria, who was not yet treated with insulin, suggests that human diabetes mellitus is not associated with an increase of digestive mucosal enzymes.

We did, however, find, in accordance with Cerda et al. [6] and Arvanitakis and Olson [2], elevated disaccharidase (maltase, sucrase) and alkaline phosphatase activities in mucosa of patients with both chronic pancreatic disease and diabetes mellitus and also in patients with pancreatic disease without overt diabetes (unpublished observations). Since severe

Table 2. Digestive enzymatic activity in small bowel biopsies of juvenile and maturity onset diabetics

\begin{tabular}{|c|c|c|c|c|c|c|c|c|c|}
\hline \multirow{2}{*}{$\frac{\text { Enzyme }}{\text { Disaccharidases }}$} & \multicolumn{2}{|l|}{ Controls } & \multicolumn{4}{|c|}{ Juvenile Diabetics } & \multicolumn{3}{|c|}{ Maturity onset diabetics } \\
\hline & & & & & & & & & \\
\hline Maltase & $269 \pm 65$ & $(10)$ & $298 \pm 68$ & (5) & & s. & $351 \pm 152$ & $(10)$ & n.s. \\
\hline Sucrase & $60 \pm 18$ & (10) & $72 \pm 20$ & (5) & $\mathrm{n}$ & s. & $67 \pm 27$ & (10) & n.s. \\
\hline Lactase & $37 \pm 23$ & (10) & $40 \pm 15$ & (5) & $\mathrm{n}$ & s. & $42 \pm 27$ & (10) & n.s. \\
\hline Trehalase & $19 \pm 13$ & (10) & $25 \pm 9$ & (5) & $\mathrm{n}$ & s. & $22 \pm 10$ & (10) & n.s. \\
\hline Alkaline phosphatase & $235+76$ & (10) & $250 \pm 90$ & (5) & & s. & $268 \pm 124$ & $(10)$ & n.s. \\
\hline \multicolumn{10}{|l|}{ Peptide hydrolase activityb } \\
\hline leucyl-leucine-hydrol. & $1.48 \pm 1.1$ & $8 \quad(6)$ & $1.39 \pm 0$ & & 5) & n.s. & $1.26+1.02$ & (6) & n.s. \\
\hline leucyl-glycine-hydrol. & $0.77 \pm 0.4$ & $9 \quad(6)$ & $0.80 \pm 0$ & & 5) & n.s. & $1.28 \pm 0.80$ & (6) & n.s. \\
\hline glycyl-leucine-hydrol. & $6.49 \pm 4.3$ & $0 \quad(6)$ & $7.20 \pm 3$ & 0 & 5) & n.s. & $4.46 \pm 3.30$ & (6) & n.s. \\
\hline methionyl-leucine-hydrol. & $1.07 \pm 0.8$ & $0 \quad(6)$ & $1.40 \pm 0$ & & 5) & n.s. & $1.56 \pm 0.60$ & (6) & n.s. \\
\hline leucyl-proline-hydrol. & $0.38 \pm 0.1$ & $4 \quad(6)$ & $0.40 \pm 0$ & & 5) & n.s. & $0.36 \pm 0.18$ & $(5)$ & n.s. \\
\hline
\end{tabular}

a Specific enzymatic activity for disaccharidases and alkaline phosphatase is expressed in umoles substrate hydrolyzed $/ \mathrm{min} / \mathrm{g}$ protein.

b Specific activity of peptide hydrolase activity is expressed in $\mu$ moles substrate hydrolyzed $/ \mathrm{min} / \mathrm{mg}$ of $\mathrm{protein}$. Results are means \pm standard deviation (S.D.). The number of patients tested is given in parenthesis( ).

saccharidase activities virtually equal to jurenile diabetics receiving the last insulin injection $24 \mathrm{~h}$ before the biopsy was obtained. Peptide hydrolase activity in diabetic jejunum did not differ from controls. One 20 year old juvenile diabetic with ketonuria, whose diabetes had been just diagnosed and not yet treated with insulin, also had normal activities of disaccharidases, alkaline phosphatase and peptide hydrolases.

\section{Discussion}

These results show that intestinal mucosa of well-controlled, juvenile onset and maturity onset diabetics has normal digestive activity for hydrolysis of disaccharides and oligopeptides. Normal disaccharidase activity in six adult onset diabetics has been described recently [7]. This finding is in contra- experimental diabetes of rats induces changes in synthesis of exocrine pancreatic enzymes [17], which are reversible by insulin-treatment, the possibility exists that the increase of brush border enzymatic activity in untreated diabetic rats is mediated by an abnormal exocrine pancreatic function and is not due to a direct effect of the insulin deficiency on intestinal mucosa. An influence of exocrine pancreatic enzymes on the disaccharidase turnover in the intestinal brush borders has been reported recently [1]. Usually, exocrine pancreatic function is not or only slightly impaired in human maturity onset or juvenile diabetes $[8,15,16]$.

Acknowledgement. This work was supported by a grant from the Deutsche Forschungsgemeinschaft (Ca 71/2). Mrs. Balfanz and Miss $H$. Römhild gave valuable technical assistance in performing the enzymatic analysis of the biopsies. 


\section{References}

1. Alpers, D.H.: Mechanism of rapid disaccharidase turnover in intestinal brush borders. Clin. Res. 20, 447 (1972)

2. Arvanitakis, C., Olson, W.A.: Pancreatic disease and intestinal disaccharidase activities. Gastroenterology 64, 854 (1973) (abstr.)

3. Caspary, W.F., Rhein, A.M., Creutzfeldt, W.: Increase of intestinal brush border hydrolases in mucosa of streptozotocin-diabetic rats. Diabetologia 8, 412414 (1972)

4. Caspary, W.F.: Effect of insulin and experimental diabetes mellitus on the digestive-absorptive function of the small intestine. Digestion 9, 248-263 (1973)

5. Caspary, W.F.: Intestinalo Peptidhydrolaseaktivität im menschlichem Dünndarmbiopsiematerial - eine einfache Bestimmungsmethode. Klin. Wschr. 52, 341 $-345(1974)$

6. Cerda, J.J., Preiser, H., Crane, R.K.: Brush border enzymes and malabsorption. Elevated disaccharidases in chronic pancreatic insufficiency with diabetes mellitus. Gastroenterology 62, 841 (1972) (abstract)

7. Chaudhary, M.A., Olson, W.A.: Jejunal disaccharidase activity in maturity onset diabetes. Amer. J. Digest. Dis. 18, 199-200 (1973)

8. Chey, W.Y., Shay, H., Shuman, C.R.: External pancreatic secretion in diabetes mellitus. Ann. Intern. Med. 59, 812-821 (1963)

9. Dahlqvist, A.: Method for assay of intestinal disaccharidases. Analyt. Biochem. 7, 18-25 (1964)

10. Fujita, M., Parsons, D.S., Woinarowska, M.: Oligopeptidases of brush border membranes of rat small intestinal mucosal cells. J. Physiol. (London) 227, $377-394$ (1972)
11. Hossein, Z., Levinson, R.A., Englert, E.: Endocrine induction of small intestinal hexolinase and maltase activity. Gastroenterology 58, 961 (1970) (abstr.)

12. Lowry, O.H., Rosebrough, N.J., Farr, A.L., Randall, R.J.: Protein measurement with the Folin phenol reagent. J. biol. Chem. 193, 265-269 (1951)

13. Malathi, P., Ramaswamy, K., Caspary, W.F., Crane, R.K.: Studies on the transport of glucose from disaccharides by hamster small intestine in vitro. I. Evidence for a disaccharidase-related transport system. Biochim. biophys. Acta (Amst.) 307, 613-626 (1973)

14. Olson, W.A., Rogers, L.: Jejunal sucrase activity in diabetic rats. J. Lab. clin. Med. 77, 838-842 (1971)

15. Pekos, N., Dick, A.P., Hales, C.N.: Exocrine and endocrine pancreatic function in diabetes mellitus and chronic pancreatitis. Gut 7, 277-281 (1966)

16. Ritter, U.: Die exkretorische Pankreassekretion bei Diabetes mellitus. Dtsch. med. Wschr. 90, 1063-1064 (1965)

17. Söling, H.D., Unger, K. O.: The role of insulin in the regulation of $\alpha$-amylase synthesis in the rat pancreas. Europ. J. clin. Invest. 2, 199-212 (1972)

18. Younoszai, M.D., Schedl, H.P.: Effect of diabetes on intestinal disaccharidase activities. J. Lab. clin. Med. $\mathbf{7 9}, 579-586(\mathbf{1 9 7 2})$

Dr. W.F. Caspary

Medizinische Klinik und

Poliklinik der Universität

34 Göttingen

Humboldtallee 1

Federal Republic of Germany 